\title{
Dynamics of the transcriptome during chicken embryo development based on primordial germ cells
}

\author{
Aleksandra Dunislawska, Agata Szczerba, Maria Siwek and Marek Bednarczyk* (1)
}

\begin{abstract}
Objective: Regulation of gene expression during embryo development on the basis of migration of primordial germ cells (PGCS) in vivo has been rarely studied due to limited cell number and the necessity to isolate PGCs from a large number of embryos. Moreover, little is known about the comprehensive dynamics of the transcriptome in chicken PGCs during early developmental stages. The current study investigated transcriptome dynamics of chicken PGCs at key developmental stages: 4.5, 8 and 12 days of embryo incubation. PGCs were collected, and RNA was isolated using a commercial kit for single cells. The isolated RNA was subjected to microarray analysis (Agilent Technologies).

Results: Between 8 and 12 days of incubation, the highest number of genes was regulated. These data indicate that the most intense biological activity occurs between 8 and 12 days of embryo development. Heat map showed a significant decrease in gene expression on day 8, while it increased on day 12. The development of a precise method to isolate bird PGCs as well as the method to isolate RNA from single cells isolated from one embryo allows for early molecular analysis and detection of transcriptome changes during embryonic development.
\end{abstract}

Keywords: Gene expression, Primordial germ cells, Microarray, White Leghorn

\section{Introduction}

Primordial germ cells (PGCs) are the earliest recognisable precursors of adult germ cells. They transfer the genetic information to the next generation of cells. Chicken PGCs originate from the epiblast [1]. They are located at the centre of the area pellucida at stage $\mathrm{X}$ of Hamburger-Hamilton (HH) [2] and are translocated anteriorly to the germinal crescent [3]. Subsequently, the PGCs localise in the vascular system and use those extraembryonic blood vessels as a vehicle to reach the germinal ridges (Additional file 1: Figure S1). They accumulate in germinal ridges as gonadal PGCs (gPGCs), are also termed as gonocytes [4] and differentiate into spermatogonia in males or oogonia in females. Circulating

*Correspondence: marbed13@op.pl

Department of Animal Biotechnology and Genetics, UTP University

of Science and Technology, Bydgoszcz, Poland
PGCs and gPGCs are functionally very similar. As precursors of reproductive cells, PGCs are an important tool in the study on reproduction of vertebrates and in gene expression and epigenetic studies. The first challenge in gaining knowledge and understanding of the mechanisms associated with PGCs is to analyse the changes that may occur in a given location in the embryo on the basis of PGCs from a given place, regardless of gender. PGCs migrate into the bloodstream before they reach the gonads and are classified as circulating PGCs (cPGCs). However, the regulation of gene expression during the migration and proliferation of PGCs in vivo has been rarely studied due to limited cell number. Little is known about the comprehensive dynamics of the transcriptome in chicken PGCs isolated from a single embryo during early developmental stages. At individual stages of development, the expression of only a limited number of genes was analysed $[5,6]$. The present study aimed to analyse

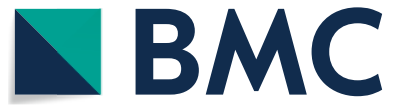

(c) The Author(s) 2020. This article is licensed under a Creative Commons Attribution 4.0 International License, which permits use, sharing, adaptation, distribution and reproduction in any medium or format, as long as you give appropriate credit to the original author(s) and the source, provide a link to the Creative Commons licence, and indicate if changes were made. The images or other third party material in this article are included in the article's Creative Commons licence, unless indicated otherwise in a credit line to the material. If material is not included in the article's Creative Commons licence and your intended use is not permitted by statutory regulation or exceeds the permitted use, you will need to obtain permission directly from the copyright holder. To view a copy of this licence, visit http://creativeco mmons.org/licenses/by/4.0/. The Creative Commons Public Domain Dedication waiver (http://creativecommons.org/publicdomain/ zero/1.0/) applies to the data made available in this article, unless otherwise stated in a credit line to the data. 
transcriptome dynamics of gPGCs at three developmental stages: day 4.5, 8 and 12 of embryo incubation.

\section{Main text \\ Methods \\ Isolation of gPGCs}

45 White Leghorn fertilized eggs were incubated at $37.8^{\circ} \mathrm{C}$ for $4.5,8$ and 12 days $\mathrm{HH}$ stages: 26,34 and 38 , respectively [7], 15 eggs for time point to obtain embryos of suitable developmental stage. The gonads were cultured for up to $90 \mathrm{~min}$ at $37.8{ }^{\circ} \mathrm{C}$ in phosphate buffered saline without $\mathrm{Ca}^{2+}$ and $\mathrm{Mg}^{2+}$ (PBS [-]) according to Nakajima et al. [8] to obtain live gPGCs. PGCs were collected in lysis buffer, and RNA was isolated using a commercial kit (GenElute Single Cell RNA Purification Kit, Sigma Aldrich, Missouri, USA). To confirm that the RNA was derived from PGCs, PGC-related markers (NANOG and $D A Z L$ ) were assessed by reverse transcription- quantitative polymerase chain reaction (RT-qPCR) based on the protocol described by Dunislawska et al. [9]. Primer sequences were derived from literature data [10].

\section{Whole transcriptome analysis}

Microarray analysis was performed using SurePrint G3 Custom GE $8 \times 60 \mathrm{k}$ microarrays. Three slides with four matrices each were used. The analysis for one time point was performed in four independent biological replicates. The microarray procedure was performed according to the manufacturer's protocol for One-Color MicroarrayBased Gene Expression Analysis (Agilent Technologies, Santa Clara, USA). The obtained data were analysed by GeneSpring GX software (Agilent Technologies). The following criteria were used to generate the gene lists: statistical significance ( $P$ value) higher than 0.05 and cut-off greater than 2.0 as upregulated genes and smaller than -2.0 as downregulated genes. Statistical analysis was performed using one-way ANOVA. Selected time points were compared with each other. For qualitative analysis, Venn diagrams (bioinformatics.psb.ugent.be/webtools/ Venn/) and a heat map were used to present the general direction of changes in the expression level. GeneSpring software was also used for qualitative assessment to assign genes to the main terms of gene ontology (GO). To analyse the interaction between individual proteins encoded by genes that showed changes in the expression level, an extended functional analysis was performed using the STRING software [11].

\section{Microarray validation}

A panel of eight high differentially expressed genes (DEGs) was selected for microarray validation by using RT-qPCR as described in Dunislawska et al. [12]. Two reference genes were used: $A C T B$ [13] and G6PDH
[14]. Sequences of primers for validation were designed based on cDNA nucleotide sequence (Additional file 1: Table S1) using NCBI Primer-Blast [15]. The relative gene expression analysis was performed using the $\mathrm{ddCt}$ method [16]. The significance of the gene expression data was determined with Student's $t$ test $(P<0.05)$.

\section{Results \\ Isolation of $g P G C s$}

RT-qPCR confirmed that the isolated RNA was derived from PGCs. Results from the amplification curve and threshold cycle $(\mathrm{Ct})$ values do not differ significantly between the developmental stages. The average $\mathrm{Ct}$ value for the NANOG gene is 27.4 while Ct of $D A Z L$ is 26 . The results of NANOG and DAZL amplification are shown in the Additional file 1: Figure S2 and S3.

\section{Quantitative analysis of DEGs}

The total number of DEGs between 4.5 and 8 days of embryo development was 403 upregulated genes and 988 downregulated genes. There were 5304 upregulated genes and 2535 downregulated genes between 8 and 12 days of embryo development. The number of DEGs between 4.5 and 12 days of embryo development was 3571 upregulated genes and 1528 downregulated genes. The results are presented in Venn diagrams in Additional file 1: Figures S4 and S5.

Heat maps (Fig. 1) show that on day 4.5 of embryo development, the expression level of the vast majority of genes was in the range of -2.2 to 2.2 . On day 8 of embryo development, the expression level of the majority of genes decreased. In contrast, gene expression was significantly upregulated on day 12 of embryo development.

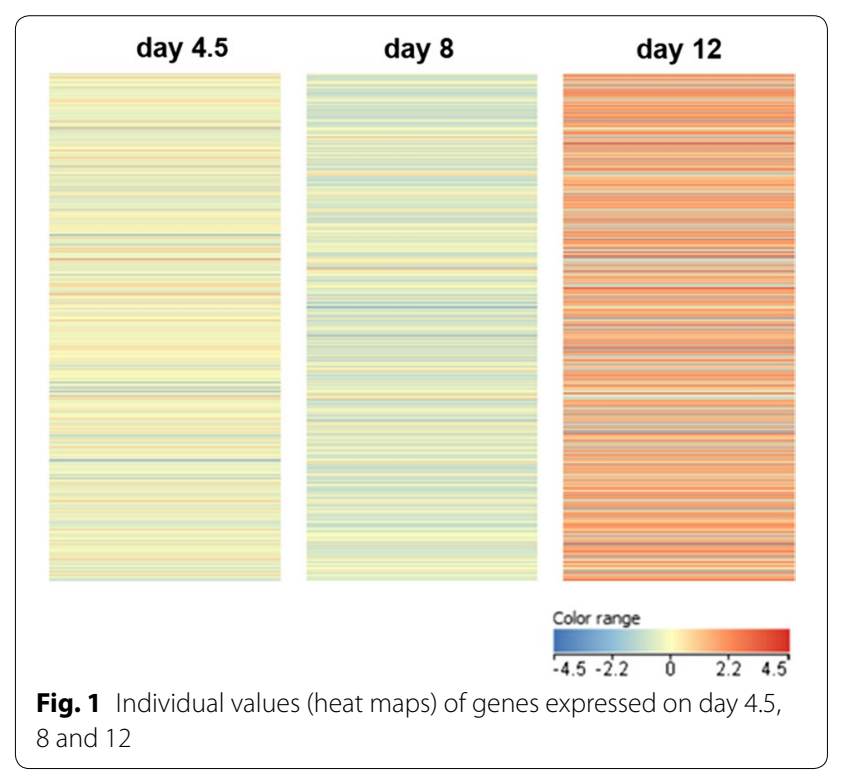




\section{Qualitative analysis of DEGs}

The results are presented only for statistically significant $(P<0.05)$ GO terms and show a comparison of gene expression on day 8 and 12 versus that on day 4.5. The analysis of GO terms showed that the genes upregulated on day 8 were allocated to the GO term related to the extracellular region (GO:0005576). The relationship between these genes is shown in Fig. 2.

The downregulated genes on day 8 were assigned to the following GO terms: cytokine receptor binding (GO:0005126) and defence response to bacterium (GO:0042742 and GO:0042830). The relationships between these genes are shown in Additional file 1: Figure S6. The highest number of genes was upregulated on day 12 (detailed data are presented in Table 1). The genes downregulated on day 12 are mostly involved in organic cyclic compound binding (GO:0097159) and heterocyclic compound binding (GO:1901363).

\section{Microarray validation}

A panel of genes was selected on the basis of the highest and lowest values of fold change on microarray. A comparison of RT-qPCR validation and microarray results is presented in the Additional file 1: Table S2. The expression patterns of the majority of these genes ( 6 out of 8) were consistent between RT-qPCR and microarray.

\section{Discussion}

The present study aimed to analyse the transcriptome of chicken PCGs at three different time points of embryo development. The motivation for this investigation was to show how quantitative gene expression in PGCs changes during chicken embryonic development. An extensive knowledge on avian PGCs has been generated from in vitro studies [17-19]. In contrast, there is limited information on the regulation of gene expression during the migration of PGCs in vivo. This is mainly because of the limited number of available PGCs [20]. The new technique for isolating viable avian PGCs combined with the method of RNA isolation from a single cell offers a

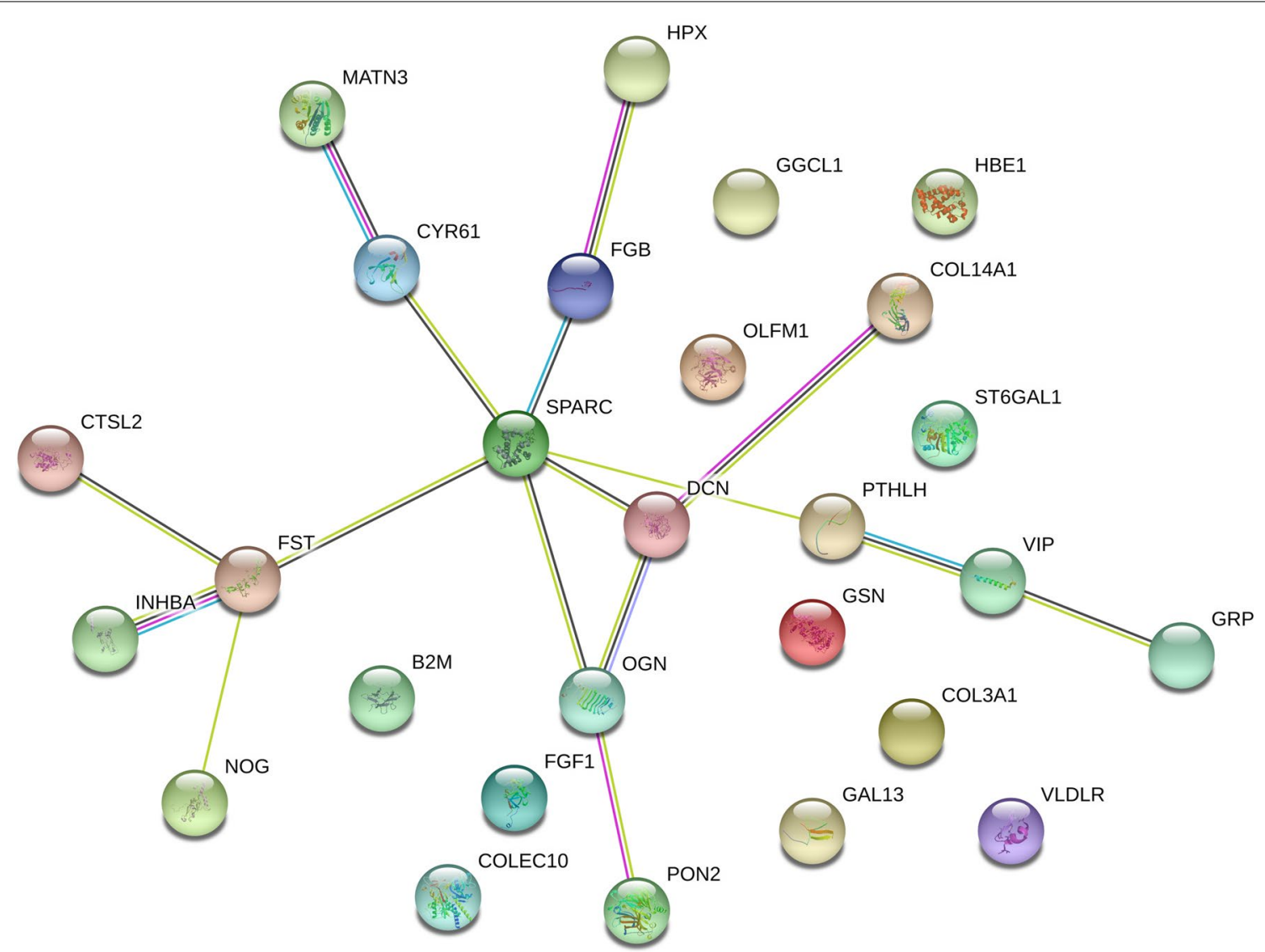

Fig. 2 Analysis of the relationship between proteins encoded by genes whose expression was upregulated in PGCs on day 8 of embryo development. Lines of interactions according to STING software: light blue-from curated databases; pink-experimentally determined; dark greengene neighborhood; red-gene fusions; dark blue-gene co-occurrence; light green-textmining; black-co-expression; violett-protein homology 
Table 1 Gene Ontology terms based on the upregulated genes on day 12 in PGCs

\begin{tabular}{|c|c|c|}
\hline GO ACCESSION & GO term & Total count \\
\hline GO:0032501 & Multicellular organismal process & 719 \\
\hline \multicolumn{3}{|l|}{ GO:0044707 } \\
\hline \multicolumn{3}{|l|}{ GO:0050874 } \\
\hline GO:0032502 & Developmental process & 662 \\
\hline \multicolumn{3}{|l|}{ GO:0044767 } \\
\hline GO:0048856 & Anatomical structure development & 634 \\
\hline GO:0007275 & Multicellular organism development & 587 \\
\hline GO:0071944 & Cell periphery & 462 \\
\hline GO:0005886| GO:0005904 & Plasma membrane & 447 \\
\hline GO:0023052 & Signaling & 446 \\
\hline \multicolumn{3}{|l|}{ GO:0023046 } \\
\hline \multicolumn{3}{|l|}{ GO:0044700 } \\
\hline GO:0007165 & Signal transduction & 423 \\
\hline \multicolumn{3}{|l|}{ GO:0023033 } \\
\hline GO:0005576 & Extracellular region & 308 \\
\hline GO:0044459 & Plasma membrane part & 258 \\
\hline GO:0044421 & Extracellular region part & 232 \\
\hline GO:0005615 & Extracellular space & 212 \\
\hline GO:0003008 & System process & 155 \\
\hline GO:0031226 & Intrinsic component of plasma membrane & 146 \\
\hline GO:0005887 & Integral component of plasma membrane & 140 \\
\hline GO:0006811 & Ion transport & 132 \\
\hline GO:0050877 & Nervous system process & 96 \\
\hline GO:0007600 & Sensory perception & 57 \\
\hline GO:0007601 & Visual perception & 33 \\
\hline GO:0050953 & Sensory perception of light stimulus & 33 \\
\hline GO:0006936 & Muscle contraction & 22 \\
\hline
\end{tabular}

unique approach for the study of cell transcriptome dynamics. In the current study, both techniques were combined together for the first time. We isolated PGCs in vivo directly from the embryo and subjected them to the transcriptome analysis of RNA isolated from single cells. Earlier studies were based on in vitro cultures [21] and thus do not reflect the complexity of living organisms. The objective of these studies was to obtain PGCs from a large number of embryos $[6,22]$.

The transcriptome analysis was performed at three specific time points of embryo development: day 4.5, 8 and 12. According to the available literature, the germ cells of most species undergo two complex developmental phases [23]. The first phase occurs during early embryogenesis. PGCs are formed in this phrase, and they then actively migrate to the gonads. In the second phase, the germ cells initiate one of the two distinct programs of cell division: meiosis and differentiation-oogenesis or spermatogenesis to form gametes [24]. However, very little is known about the molecular mechanisms that govern these programs. Therefore, we used the transcriptome analysis to detect dynamic changes of gene expression in gPGCs at three developmental stages. According to Swartz and Domm [25], an increase in the number of PGCs is observed during the embryonic period from the start of migration to 5 days of incubation. During this period, the number of PGCs ranged from 43 to 2211 . A period of intense proliferation is observed between the fourth and fifth day of embryo development. Therefore, the first data point for the transcriptome analysis of PGCs was set at day 4.5 of embryo development. Méndez et al. [26] indicated the variation in the time of growth in chick gonad depends on the sex of the embryo. At 8 days of incubation, the left ovary initiates a period of exponential growth, as shown by the increase in the total number of somatic cells. A similar pattern of increment was observed in the number of germ cells of the chick embryo ovary. This was the reason for selecting day 8 as the second data point for the transcriptome analysis of PGCs. The last data point, i.e. day 12 , was selected because of somatic conversion [27]. This process involves rearrangement of immunoglobulin genes. In birds, it occurs only 
once during the entire lifetime in the course of embryonic development.

The present study showed the highest number of upregulated DEGs on day 12 of embryo development. The expression of these genes is mainly associated with biological pathways such as multicellular organismal processes, developmental process and anatomical structure development. On day 8 of embryo development, a significant decrease in gene expression was observed. We assume that there is a negative regulation in the 8th day in relation to day 4.5 , because there is no more increased cell migration and proliferation that may take place on day 4.5. Significant upregulation at day 12 is likely to be associated with a number of immune processes. Also, environmental effects of $\mathrm{CpG}$ island methylation, which may lead to gene expression silencing, cannot be clearly excluded [28]. The common denominator for the observed relationships among the upregulated genes on day 8 is the SPARC gene. This protein regulates cell growth by interacting with the extracellular matrix and cytokines. The relationships among genes with negative expression in PGCs on day 8 of embryo development relative to day 4 are derived from the SERPINB10 and INS genes. SERPINB10 plays a role in regulating protease activity during apoptosis. INS plays an important role in carbohydrate and lipid metabolism by increasing cell permeability to monosaccharides, amino acids and fatty acids.

These results shed new light on the transcriptome analysis of PGCs, treating them as a tool for the global view of embryonic development. Changes in gene expression depend on the time point of PGCs isolation during embryonic development. This study shows that on all the analysed days, i.e. $4.5,8$ and 12 , PGCs are present in the gonads and show significant transcriptional activity.

\section{Limitations}

The present study aimed to show how quantitative gene expression in PGCs changes during chicken embryonic development. However, we did not determine the sex of PGC embryo donors. Further studies are needed to clarify the effect of the sex of the embryo on the transcriptome of chicken PGCs.

\section{Supplementary information}

Supplementary information accompanies this paper at https://doi. org/10.1186/s13104-020-05286-w.

Additional file 1: Figure S1. Migration of chicken PGCs in early embryogenesis (according to Kuwana T., 2018, unpublished). Figure S2. NANOG gene amplification curve based on RNA isolated from gonadal PGCs collected from 3 stages of embryonic development: 4.5, 8 and 12.. Figure S3. DAZL gene amplification curve based on RNA isolated from gonadal PGCs collected from 3 stages of embryonic development: 4.5, 8 and 12 .
Figure S4. The number of differentially expressed genes showing up regulation (cut off $>2.0$ ) of expression in primordial germs cells detected between embryo development days: 12 vs 4.5 (blue), 8 vs 4.5 (red) and 8 vs 12 (green). Figure S5. The number of differentially expressed genes showing down regulation (cut off $>2.0$ ) of expression in primordial germs cells detected between embryo development days:12 vs 4.5 (blue), 8 vs 4.5 (red) and 8 vs 12 (green). Figure S6. Analysis of the relationship between proteins encoded by genes whose expression was downregulated in PGCs on day 8 of embryo development. Lines of interactions according to STING: light blue - from curated databases; pink - experimentally determined; dark green - gene neighborhood; red - gene fusions; dark blue - gene co-occurrence; light green - textmining; black - co-expression; violett - protein homology. Table S1. List of selected genes for microarray validation with designed primer sequences for $R T-q P C R$ reaction. Table S2. Microarray validation. Results of RT-qPCR analysis for panel of the most up or down expressed genes selected from microarrays results in 3 stages of embryo development. *statistically significant $(P<0.05)$.

\section{Abbreviations}

PGCs: Primordial germ cells; cPGCs: Circulating primordial germ cells; gPGCs: Gonadal primordial germ cells; DEGs: Differentially expressed genes; Ct: Threshold cycle; RT-qPCR: Reverse transcription-quantitative polymerase chain reaction.

\section{Acknowledgements}

Not applicable.

\section{Authors' contributions}

AD developed methodology of RNA isolation, RTq-PCR and methodology, performed RT-qPCR and microarray analysis, was a major contributor in writing the manuscript. AS performed PGCs and RNA isolation. MS reviewed and edited the manuscript. MB acquired the funding, developed experimental setup and methodology od PGCs isolation, was a major contributor in writing the manuscript. All authors read and approved the final manuscript.

\section{Funding}

The research was supported by Grant UMO-2017/27/B/NZ9/01510 funded by the National Science Centre in Cracow (Poland).

\section{Availability of data and materials}

The datasets used and/or analyzed during the current study are available from the corresponding author on reasonable request.

\section{Ethics approval and consent to participate}

Not applicable.

\section{Consent for publication}

Not applicable.

\section{Competing interests}

The authors declare that they have no competing interests.

Received: 3 July 2020 Accepted: 11 September 2020

Published online: 18 September 2020

\section{References}

1. Eyal-Giladi H, Ginsburg M, Farbarov A. Avian primordial germ cells are of epiblastic origin. J Embryol Exp Morphol. 1981;65:139-47.

2. Eyal-Giladi $\mathrm{H}$, Kochav S. From cleavage to primitive streak formation: a complementary normal table and a new look at the first stages of the development of the chick. I. General morphology. Dev Biol. 1976:49:321-37.

3. Tagami T, Kagami H. Developmental origin of avian primordial germ cells and its unique differentiation in the gonads of mixed-sex chimeras. Mol Reprod Dev. 1998;50:370-6. https://doi.org/10.1002/(SICI)10982795(199807)50:3\%3c370:AID-MRD14\%3e3.0.CO;2-8. 
4. Collarini EJ, Leighton PA, Van de Lavoir M-C. Production of transgenic chickens using cultured primordial germ cells and gonocytes. Methods Mol Biol. 2019. https://doi.org/10.1007/978-1-4939-8831-0_24.

5. Motono M, Ohashi T, Nishijima KI, lijima S. Analysis of chicken primordial germ cells. Cytotechnology. 2008;57:199-205.

6. Han JY, Park TS, Kim JN, Kim MA, Lim D, Lim JM, et al. Gene expression profiling of chicken primordial germ cell ESTs. BMC Genomics. 2006;7:220.

7. Hamburger $\mathrm{V}$, Hamilton $\mathrm{HL}$. A series of normal stages in the development of the chick embryo. J Morphol. 1951:88:49-92.

8. Nakajima Y, Minematsu T, Naito M, Tajima A. A new method for isolating viable gonadal germ cells from 7-day-old chick embryos. J Poult Sci. 2011;48:106-11.

9. Dunislawska A, Slawinska A, Stadnicka K, Bednarczyk M, Gulewicz P, Jozefiak D, et al. Synbiotics for broiler chickens - in vitro design and evaluation of the influence on host and selected microbiota populations following in ovo delivery. PLoS ONE. 2017;12:e0168587. https://doi. org/10.1371/journal.pone.0168587.

10. Choi JW, Kim S, Kim TM, Kim YM, Seo HW, ParkTS, et al. Basic fibroblast growth factor activates MEKJERK cell signaling pathway and stimulates the proliferation of chicken primordial germ cells. PLOS ONE. 2010;5:e12968. https://doi.org/10.1371/journal.pone.0012968.

11. Szklarczyk D, Franceschini A, Kuhn M, Simonovic M, Roth A, Minguez P, et al. The STRING database in 2011: functional interaction networks of proteins, globally integrated and scored. Nucleic Acids Res. 2011;39(SUPPL):1.

12. Dunislawska A, Slawinska A, Bednarczyk M, Siwek M. Transcriptome modulation by in ovo delivered Lactobacillus synbiotics in a range of chicken tissues. Gene. 2019;698:27-33. https://doi.org/10.1016/J. GENE.2019.02.068.

13. De Boever S, Vangestel C, De Backer P, Croubels S, Sys SU. Identification and validation of housekeeping genes as internal control for gene expression in an intravenous LPS inflammation model in chickens. Vet Immunol Immunopathol. 2008;122:312-7. https://doi.org/10.1016/j.vetim m.2007.12.002.

14. Sevane N, Bialade F, Velasco S, Rebolé A, Rodríguez ML, Ortiz LT, et al. Dietary inulin supplementation modifies significantly the liver transcriptomic profile of broiler chickens. PLoS ONE. 2014;9:e98942.

15. Ye J, Coulouris G, Zaretskaya I, Cutcutache I, Rozen S, Madden TL. Primer-BLAST: a tool to design target-specific primers for polymerase chain reaction. BMC Bioinformat. 2012;13:134. https://doi. org/10.1186/1471-2105-13-134.

16. Livak KJ, Schmittgen TD. Analysis of relative gene expression data using real-time quantitative PCR and the 2(-Delta Delta C(T)) Method. Methods. 2001;25:402-8. https://doi.org/10.1006/meth.2001.1262.
17. Raucci F, Fuet A, Pain B. In vitro generation and characterization of chicken long-term germ cells from different embryonic origins. Theriogenology. 2015;84(732-742):e2. https://doi.org/10.1016/j.theriogeno logy.2015.04.032.

18. Pérez Sáez JM, Bussmann LE, Barañao JL, Bussmann UA. Improvement of Chicken Primordial Germ Cell Maintenance In Vitro by Blockade of the Aryl Hydrocarbon Receptor Endogenous Activity. Cell Reprogram. 2016;18:154-61.

19. Chen Y-C, Lin S-P, Chang Y-Y, Chang W-P, Wei L-Y, Liu H-C, et al. In vitro culture and characterization of duck primordial germ cells. Poult Sci. 2019;98:1820-32. https://doi.org/10.3382/ps/pey515.

20. Sopiyana S, Setiadi MA, Fahrudin M, Supriatna I. Isolation and number of gonadal primordial germ cells (gonadal PGCs) on the stages of early embryonic development of KUB chicken. Media Peternak. 2017;40:1-6.

21. Jean C, Oliveira NMM, Intarapat S, Fuet A, Mazoyer C, De Almeida I, et al. Transcriptome analysis of chicken ES, blastodermal and germ cells reveals that chick ES cells are equivalent to mouse ES cells rather than EpiSC. Stem Cell Res. 2015;14:54-67.

22. Jang H-J, Seo HW, Lee BR, Yoo M, Womack JE, Han JY. Gene Expression and DNA Methylation Status of Chicken Primordial Germ Cells. Mol Biotechnol. 2013;54:177-86. https://doi.org/10.1007/s12033-012-9560-5.

23. Castrillon DH, Quade BJ, Wang TY, Quigley C, Crum CP. The human VASA gene is specifically expressed in the germ cell lineage. Proc Natl Acad Sci USA. 2000;97:9585-90.

24. Nikolic A, Volarevic V, Armstrong L, Lako M, Stojkovic M. Primordial germ cells: Current knowledge and perspectives. Stem Cells Int. 2016;2016:1741072.

25. Swartz WJ, Domm LV. A study on division of primordial germ cells in the early chick embryo. Am J Anat. 1972;135:51-69. https://doi.org/10.1002/ aja.1001350106.

26. Méndez C, Carrasco E, Pedernera E. Adenohypophysis regulates cell proliferation in the gonads of the developing chick embryo. J Exp Zool Part A Comp Exp Biol. 2005;303:179-85. https://doi.org/10.1002/jez.a.141.

27. Ratcliffe MJH. Antibodies, immunoglobulin genes and the bursa of Fabricius in chicken B cell development. Dev Comp Immunol. 2006:30:101-18.

28. Curradi M, Izzo A, Badaracco G, Landsberger N. Molecular Mechanisms of Gene Silencing Mediated by DNA Methylation. Mol Cell Biol. 2002;22:3157-73. https://doi.org/10.1128/mcb.22.9.3157-3173.2002.

\section{Publisher's Note}

Springer Nature remains neutral with regard to jurisdictional claims in published maps and institutional affiliations.
Ready to submit your research? Choose BMC and benefit from:

- fast, convenient online submission

- thorough peer review by experienced researchers in your field

- rapid publication on acceptance

- support for research data, including large and complex data types

- gold Open Access which fosters wider collaboration and increased citations

- maximum visibility for your research: over $100 \mathrm{M}$ website views per year

At BMC, research is always in progress.

Learn more biomedcentral.com/submissions 